\title{
Controversy over AIDS virus extends to name
}

\section{Washington}

MORE than a year of patient negotiations to choose a new name for the virus associated with acquired immune deficiency syndrome (AIDS) ended last week in a hectic torrent of letters, leaks and rearranged release dates. Two key members of the naming committee have refused to go along with human immunodeficiency virus (HIV) as a replacement for HTLVIII/LAV, but support for a new name is strong; HIV could well be the eventual choice.

The name change is proposed in a letter published elsewhere in this issue (see $p$. 10) and simultaneously in Science. The letter is the result of a year's deliberations by a specially empanelled subcommittee of the International Committee on the Taxonomy of Viruses (ICTV). Chaired by Harold Varmus of the University of California at San Francisco, the subcommittee consisted of the six members of the ICTV retrovirus study group (John Coffin, Natalie Teich, Kumao Toyoshima, Varmus, Robert Gallo and Max Essex), as well as seven members directly involved in AIDS research or familiar with the field (Ashley Haase, Jay Levy, Luc Montagnier, Steven Oroszlan, Howard Temin, Peter Vogt and Robin Weiss).

By February this year, the committee had tentatively agreed on HIV, and the name was proposed to ICTV's executive committee. David W. Kingsbury, who heads ICTV's human virus subcommittee, says that all 12 of the responses received so far from the 17 executive committee members are favourable to the new name.

But HIV never had unanimous support from Varmus's subcommittee. Nearly half of the members preferred the current compound name, HTLV-III/LAV. Others, including Gallo of the National Institutes of Health (NIH) in Bethesda, Essex of the Harvard School of Public Health and Temin of the University of Wisconsin, preferred human retrovirus (HRV), with numbers assigned sequentially for every new virus. But committee members were anxious to find a name that would eliminate disputes over priority of discovery; for that purpose, HRV was too nonspecific for most committee members.

Armed with a positive response from the ICTV executive committee, Varmus then sent to Nature and Science a letter proposing the new name, saying a full list of signatories would follow. But the announcement of new human retroviruses late in March dashed hopes for unanimity for HIV.

The new viruses, called LAV-2 by Montagnier of the Institut Pasteur and HTLV-IV by Essex, may turn out to be variations of the same virus. Montagnier announced his discovery at a meeting in Lisbon before it had been accepted for publication in any journal (see Nature 320, 3 ; 1986). Montagnier's announcement

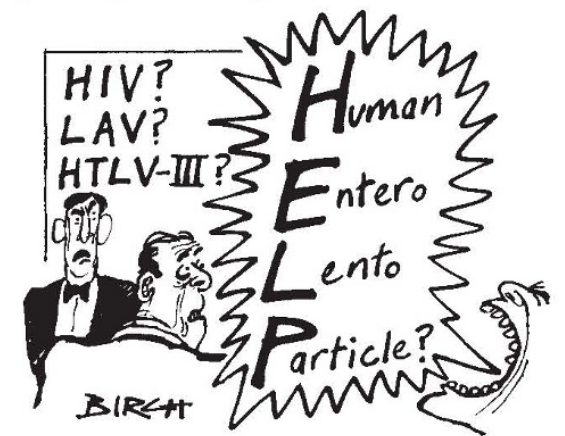

came slightly more than a week before publication (in Science) of Essex's discovery. Essex was incensed by Montagnier's action, and he informed Varmus that he would have nothing to do with the new name, already supported by Montagnier.

Essex says he had never been satisfied with HIV as a name for the AIDS virus. $\mathrm{He}$ feels that the name HTLV-III/LAV is so ingrained in the literature that it will not be possible to change it, and calls the committee's efforts "shortsighted". He is also concerned that the new nomenclature would not be appropriate for HTLV-IV, as it does not cause immune deficiency.

Shortly after Essex's decision, Gallo indicated that he would not go along with HIV either. Gallo's attitude hardened further when, two weeks ago, Montagnier delivered a lecture at NIH where he mentioned HIV. A reporter, alerted by Institut Pasteur's New York public relations company, attended the meeting, and a report that HIV would replace HTLV-III/ LAV appeared in the Washington Post on 19 April.

Gallo was furious. Varmus had decreed that no subcommittee member should discuss the new name with the press before it appeared in a scientific journal. Outraged that Montagnier should have made his announcement "right under my nose", Gallo wrote to Varmus exhorting him to withdraw his letter to Science and Nature, and saying that he should reconsider the new name.

Varmus was also furious with Montagnier for leaking the new name prematurely, but felt that Essex and Gallo were being churlish not to go along. After consultation with editors John Maddox of Nature and Dan Koshland of Science, it was agreed that the letter proposing the new name would appear as soon as possible. A contentious sentence asking editors printing the letter to "urge" authors to use the new name was dropped in the final version.

As for the name itself, even Varmus concedes that HIV has problems, but he believes it represents a reasonable compromise. Several committee members conceded that HIV was not their first chose, but were willing to compromise and to accept it.

David Baltimore, who is heading a study of AIDS for the National Academy of Sciences Institute of Medicine, says the AIDS virus was "crying out" for a name change. Baltimore shares the opinion voiced by many that, because HTLV-III is too dissimilar from its numerical ancestors HTLV-I and II to share the name, a change is needed to eliminate confusion on that point. But supporters of the name HTLV, chosen originally by Gallo in the mistaken belief that it would be closely related to HTLV-I and II, argue that hepatitis $\mathrm{A}$ and $\mathrm{B}$ are even more dissimilar from each other than are the HTLV viruses, but that those two names coexist without controversy.

Gallo says that he used HTLV-III only after a protocol for naming new human retroviruses had been agreed by an international ad hoc committee formed at a Cold Spring Harbor symposium in September 1983. But it is precisely because controversy has arisen over the virus responsible for AIDS, says Kingsbury, that the committee has sought a new name.

Steve Gillis of Immunex Corporation at Seattle, Washington, who is familiar with controversies over new names from his own experience with lymphokines, questions whether a name that is not supported by Gallo can win general support. In addition to Gallo and Essex, a prominent AIDS researcher who asked not to be identified indicated that he will not use the new name.

But support for HIV is already growing among people in the field. Baltimore has already begun to use the name, and Jerome Groopman of Harvard Medical School has included it in a draft of a paper he is preparing.

By the end of the week before publication of the Varmus letter, Gallo was insisting that he would never use HIV when referring to his original isolates, but he might consider using HIV to refer to a "generic" AIDS virus.

Formal endorsement from ICTV for HIV is expected to come in May. But, as ICTV chairman Fred Brown puts it, any name is acceptable "so long as people know what you are talking about".

Joseph Palca 